\title{
ANALYSIS OF GLOBAL FINANCIAL MARKETS AND ITS FUTURE PERSPECTIVES
}

\author{
Alina Kvietkauskiené ${ }^{1}$, Raimonda Martinkutè-Kauliené ${ }^{2}$ \\ Department of Finance Engineering, Faculty of Business Management, \\ Vilnius Gediminas Technical University, Saulettekio al. 11, Vilnius, Lithuania \\ E-mails: 'alina.kvietkauskiene@vgtu.lt (correspondingauthor);2raimonda.martinkute@vgtu.lt
}

\begin{abstract}
The authors concentrate their attention on the future perspectives of financial markets. But on the other hand the investors, in order to make efficient investment decisions, should know the real situation in financial markets. The purpose of the article is to analyze the situation in the global financial markets, as well as their development trends in the future. In order to reach the purpose the authors perform the analysis of financial markets, considering results of main asset classes, evaluating the EPS growth and the level of risk in global equity and commodity markets and examining other important factors, which affect the financial markets and the investments in different financial instruments.
\end{abstract}

Keywords: financial markets, globalization, investments, equities, financial instruments.

JEL Classification: G1; G11; G17; G24.

\section{Introduction}

All over the world it is accepted that financial market plays a very important role in the economic area. Even economics as a science is based on the capacity of the financial system and suitability of financial information for measurement of economic processes. It could be stated that other economic sectors of the country are dependent on the successful functioning of financial markets because production and efficiency can be increased. Financial markets are important conditions of movement of financial resources to the spheres where the efficiency of these resources would be the biggest. Because of the financial markets individuals and companies can manage their finance and make financial decisions.

Created general financial and investment environment, integration and liberalization of national financial markets are main features of globalization processes in financial markets. Financial globalization provides an effective intermediation between savings and investment on a global scale.

Efficient allocation of capital, higher investments in perspective branches of country's economy, risk sharing, higher returns from investments and other benefits are emphasized when talking about global financial markets. But the problem exists that besides benefits financial integration can increase the risk and even cause crises. Financial globalization increases the risk of adverse economic downturn. Capital flows coming into the local markets sometimes determine growth of real exchange rate and creates a disproportionately large financial surpluses. In such a case the lack of supervision can lead to financial crisis. It is necessary to understand the essence of those risks and find the way how to manage them in order to use the benefits of globalization.

The object of the article is the global financial markets.

The purpose of the article is to analyze the situation in the global financial markets, as well as their development trends in the future.

In order to achieve the purpose of the article, some tasks had to be fulfilled:

- to analyse the globalization impact on financial markets;

- to present the main benefits and risks of globalization ;

- to evaluate the changes in the global financial markets;

- to distinguish the future trends of analysed markets;

- to make the conclusions and suggestions for investors.

The analysis of selected markets was performed during the period of 2015 years, in order to highlight particular trends also were analyzed the period of 2013-2014 years and the perspectives for 2016 years.

Research methods used in the article are comparative and systemic analysis of scientific literature, systematic analysis of statistical data, synthesis, generalizations, graphical presentation. 


\section{Analysis of globalization aspects in financial markets}

The globalization concept formed in the second half of XX century. It is generally understood that we live in a globalized world. It is generally understood that we live in a globalized world. Most modern theorists supports the view that globalization is associated with the fundamental space, distance, time, and the existence of social change, which is as large as the changes of human activities and relationships (Urbšienè 2011).

However, the globalization concept is not well defined, and its content is more intuited than clearly perceived. "And that leads to the conclusion that globalization has not yet become a scientific term that reflects the reality of a defined dimension" (Gylys 2003).

The concept of globalization was examined by a large volume of foreign authors (Held et al. 2002; Giddens 1996; Baldwin, Martin 1999; Scholte 2005; Dreher et al. 2008). The different methodological approach represents a different phenomenon of thinking, understanding, interpretation of these events and thus the difference in performance.

Globalization can mean increasing integration between markets and states, decreasing geographic restrictions on social and cultural measures, increasing the spread of ideas and technology and the penetration of international power centers of the threats posed by the state or its sovereignty, its economic and social sustainability (Urbšienè 2011).

Beck (2001) defines globalization as not choice of business, countries or organizations. He asserts that in order to understand the meaning of globalization, it is necessary to analyze not only the economic effects of globalization, but also political and cultural, there is a need to examine the nature of globalization.

The financial market is one of the economic areas, which is characterized as the whole of measures, by which are compatible available funding supply and demand and where market price of funds is forming. The modern the financial system is institutional structure, which formed over a relatively long period of time. The globalization of financial markets is the integral part of economic dimension of globalization and can take many forms in different financial system areas:

- the openness of market and mobility of capital growth;

- the processes of national financial systems integration into the global financial system;
- the liberalization of international transactions, carried out using a variety of financial instruments;

- increasing intertwining level across countries financial markets.

The dominant view of globalization formed the impression that the financial markets have provided the unlimited possibilities for humanity. In order to evaluate and compare the degree of financial markets globalization, it is very important to measure the level of globalization correctly. In order to measure financial globalization many authors used different indicators and different ratios depending of the study purpose and globalization concept understanding.

The globalization processes in financial markets were examined by individual scientist and national or international institucions such as The World Bank. A big number of studies of financial globalization appeared after Fischer (1997) report in the annual meeting of International Monetary Fund.

According to Held et al. (2002), the process of globalization takes place on global equity interests.

World economies are increasingly integrated into the global economy. Such process is conditioned by the stimulus strength of globalization. The following reasons and assumptions of globalizationcan be distinguished: the convergence of existence quality, the global use of land resources, globalization challenges for state of the sustainability, the economic efficiency of development, discoveries and technological opportunities, communication improvement, cross-cultural integration, adequate opportunities of education and qualification, fundamental scientific discoveries and technological opportunities (see Fig. 1).

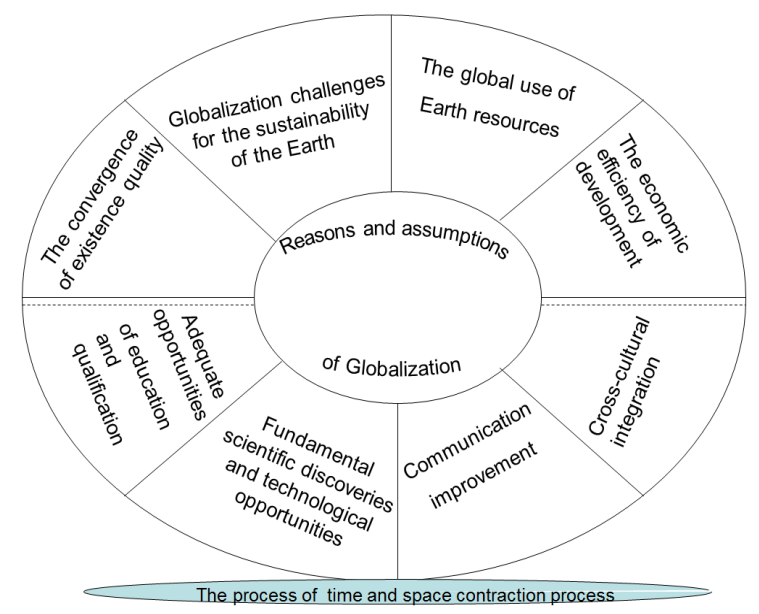

Fig. 1. The reasons and assumptions of globalization process (Source: Rutkauskas et al. 2014) 
These are the main factors that create the potential for economic activity and its entities for allocation of resources on a global scale (Rutkauskas et al. 2014).

Whereas a globalization of financial markets is the economic globalization component, it would be logical to say that the same factors operate the processes of financial markets globalization that led to the globalization process in general: economic, technological, social and political forces (Amit, Zot 2004; Stonenhouse et al. 2004; Mikdashi 2003; Gatignon, Kimberly 2004; Kropas 2007; Isard 2005) (see Fig. 2).

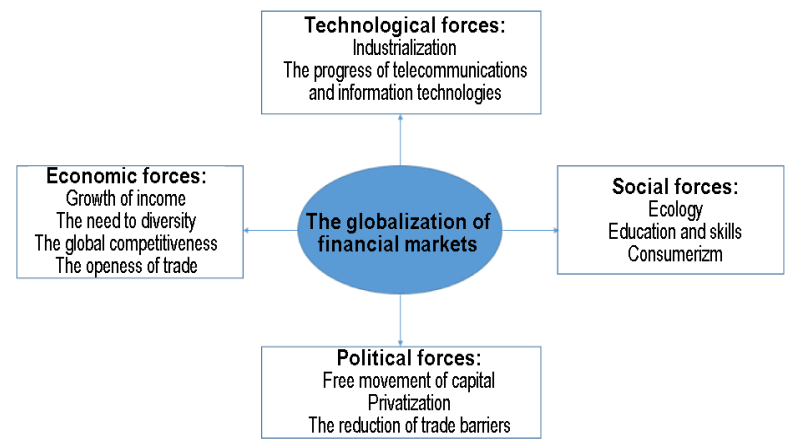

Fig. 2. The factors of financial market globalization (Source: created by authors, according to Stonenhouse et al. 2004; Gatignon, Kimberly 2004)

Globalisation has not only positive but also negative influence. Although the proponets of globalization argue that positive aspects counterbalance the negative, the criticism of globalization impact on financial market is stronger. Bhagwati (1998) argues that the risk of financial market globalization is greater than its benefits. According to scientists, growing level of globalization, increase its negative impact and global nature threats. Separate countries have not been able to solve global problems or formulate global decisions. For this purpose, a series of internation institution (such as International Monetary Fund, World Bank, the Basel Committee, etc.) has been established in the financial sector. However, globalization processes develop faster ant the non-compliance is increasingly deepening of globalizing financial markets and international institutions develolopment level (Gatignon, Kimberly 2004; Soros 2002). So the authorities of this institutions to reduce thretats of gloabalization are weakened. These „supranational“ institutions (World Bank, International Monetary Fund and others) are also criticized for partiality, by claiming that they represent the rich countries and major international companies rather than for local companies or the developing countries, which are the most vulnerable (Stiglitz, Charlton 2006; Elliott et al. 2004).
The negative impact of globalization consists in the fact that countries are losing political independence, they become more vulnerable, instability and other threats are incresing. Globalization does not reduce, but increas income inequality between countries and inside the countries.

Mundell (Mundell 1997) distinguishes one globalization negative influence - the loss of menetary policy autonomy. From the three the monetary policy objectives (capital mobility, independent monetary policy and exchange rate stability) at the same time can be achieved only two, sacrificing the third objective (see Fig. 3).

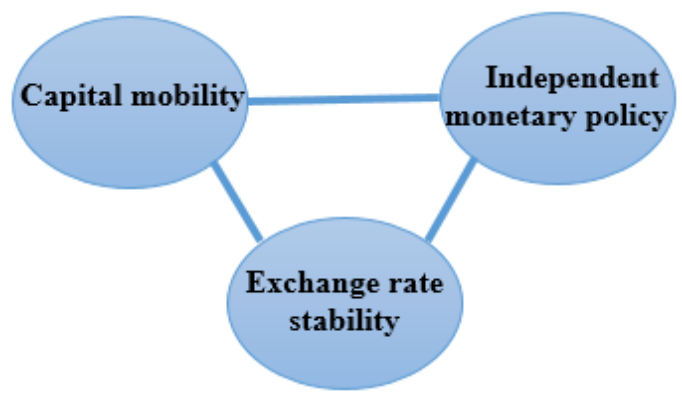

Fig. 3. The trilemma of monetary policy (Source: Mundell 1997)

Other authors consider (Brakman et al. 2010) the refusal of monetary policy autonomy as not disadvange, but advantage, because the opportunity to use monetary policy for short-term goals is eliminated, which leads to higher inflation in the long term, the GDP growth slows down and the people's social welfare become worse. However, the crisis consequences become more severe (higher GDP decline, a longer recovery period, higher number of banks bankruptcies), if during the crisis monetary policy instruments can not be applied (Bordo et al. 2001).

\section{Benefits and risk factors affecting global financial markets}

Various concepts of risk can be found in scientific literature. This leads the complexity and inconsistency of risk phenomenon. Risk can be defined as effect of uncertainty on objectives (Hopkin 2010). As it is known, uncertainty exists in financial markets, so investors encounter with uncertainty all the time, and in this case take the risk.

When talking about investments, it should be known that stock market investments are risky, because stock returns are volatile and uncertain. In highly volatile financial markets - risk and uncertainty are universal features of economic activity. In capitalist economies, uncertainty is paramount. 
Sometimes it arises from competition because the profitability of investments depends on the unknown activities of other market subjects (Beckert, Berghoff 2013).

In the early 1990s large expansion in international transactions and investments can be seen. Developed and emerging markets become more integrated into the global financial market,interest in financial globalization has increased. According to Schmukler (Schmukler 2004), financial globalization can be understood as the integration of a country's local financial system with international financial markets and institutions. This integration requires that governments liberalize the domestic financial sector and the capital account. Integration takes place when liberalized economies experience an increase in cross-country capital movement, including an active participation of local borrowers and lenders in international markets and a widespread use of international financial intermediaries (Schmukler 2004).

Many authors analysed connections between globalization of financial markets and economic growth, benefits and risks of financial integration of separate markets (Kose et al. 2010; Obstfeld 2011; Calvo 2011; Lane, Milesi- Ferretti 2010; Ceballos et al. 2012).

It is obvious that financial globalization can lead to large benefits, especially to the development of the financial system. But according to anaysed authors, financial globalization can also come with crises and contagion that is it brings some riks factors together. Sergio et al. (2004) states that various types of risks are more prevalent after countries liberalize their markets and the effect of globalization is positive in the long period. As financial systems turn global, governments lose policy instruments, so there is an increasing scope for some form of international financial policy cooperation (Sergio et al. 2004; Ceballos et al. 2012).

According to professor Issing (2000) financial globalization has many benefits. He distinguishes such benefits of financial globalization:

1) more flexible way of financing current account deficits;

2) possibility to recycle current account surpluses;

3) rapid spread of technological and financial inovations

It can be concluded that the main benefit of financial markets globalization for emerging markets is the development of its financial system. It becomes more stable than before, deeper and better-regulated.
Reward always is connected with some kind of risk. Globalization of financial markets alsocarries some risks. As the benefits of globalization appear in th long period, the risk are likely to appear in the short period of time. The main and mostly known risk factor of globalization is possibility to cause financial crises. Susch cases as Asian and Russian crises in 1997-1998, Argentina case in 2001, case of Urugay in 2002, USA 20082009 (Schmukler 2004) and other are good examples of risks of globalization. In the case of global markets the effect of crises is not just local but global too. According to Schmukler (2004) healthy local financial systems can be corrupted by some inappropriate financial means or financial infrastuctures. In order to benefir from globalization funadmantals of local financial system has to be strong, properly regulated and supervised, in other case domestic and foreign investors can use speculative attacs. Without strong fundamentals countries are more sensitive for financial shocks and crises.

Market inefficiency is is one of the risk sources for financial stability. According to the Issing (2000) inefficiency occurs because of rtansaction costs and asymmetric information, and this lead to financial crises. Electronification of financial proceses, safe procedures is important. Information problems occur when borrowers and lenders are not able to exchange all the information that would be required in order to conduct transactions in an efficient manner (Issing 2000). These problrms are espacialy important in banking system.

Other authors (Sandoval, Franca 2012; González-Hermosillo 2008) exclude four global market risk factors: funding liquidity premium, default risk, market liquidity risk and equity market volatility. Esqueda et al. (2012) state that local markets and global markets are more connected in the case of greater openness to world markets and the volatility of stock markets can increase,

In the their research about relationship between financial markets and ecology, authors (Galaz, Gars et al. 2015) state that changing financial markets influence changes in global environment and may couse ecological changes. Not all investment decisions integrate ecological understanding.

It can be concluded that financial globalization means efficient global allocation of capital, higher returns for investors, market development, risk sharing and other benefits. But on the other hand, open markets are open to some kind of risk too, the risks are connected with instability and crises. Global financial system is more sensitive to 
systemic movements and shocks, risks are harder to monitor in in some cases to understand.

\section{Development trends and future perspectives of global financial markets}

At the end of 2015, two factors continue to dominate investor sentiment: United States monetary policy and China's economic slowdown. At first view, the first of these would seem to be the less threatening of the two. The Federal Reserve appears set to "finally" raise interest rates by $0.25 \%$ at its mid-December meeting. As currently the lone major central bank looking to tighten, the Federal Reserve stands in stark contrast to most of its global counterparts.

For better understanding of real situation in the financial markets for that moment, the authors analyse the results of main asset classes during 2015 years (see Fig. 4).

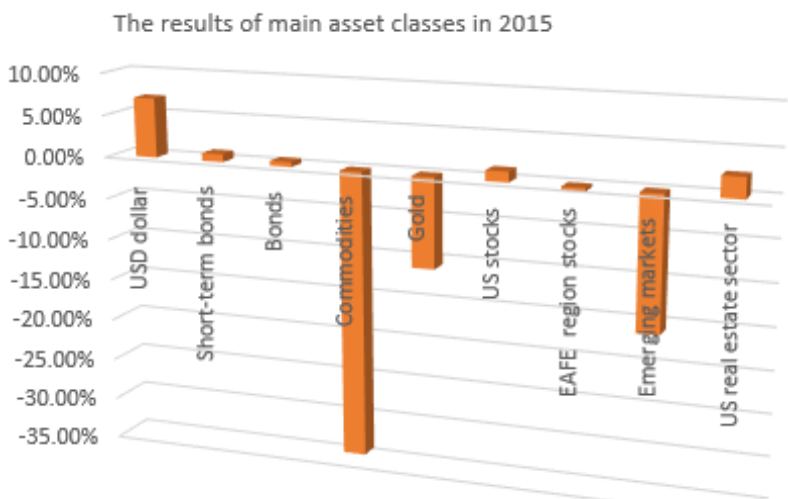

Fig. 4. The results of main asset classes in 2015 (Source: compiled by authors, according to JSC "Synergy Finance"... 2016)

These main asset classes were used for analysis (in parentheses specified related indexes):

- USD dollar (DB US dollar index);

- short-term bonds (1-5 Year Government/ Credit index);

- bonds (Barclays Capital Agregate Bond index);

- commodities (Goldman Sachs Commodity index);

- gold;

- US stocks (S\&P 500 index);

- EAFE (Europe, Australia, Asian, Asia Far East) region stocks (MSCI EAFE index);

- emerging markets (FTSE Emerging markets index);

- US real estate sector (MSCI REIT index).

The US dollar demonstrate his strength during 2015 years. United States stocks and US real estate sector generated a positive return for the second year in succession. However, EAFE and emerging markets generated negative return for the second year in succession. Commodities market suffered the greatest lost ( 5 negative year in a row). Gold crisis continues, since the peak of 2011, its price has fallen more than $40 \%$.

The investors presume that the invisible crisis began in 2015 years. This fact may be confirmed by results of stock markets in 2015 years that are provided in Table 1 .

Table 1. The results of stock markets in 2015 (Source: compiled by authors, according to JSC "Synergy Finance"... 2016).

\begin{tabular}{l|c}
\hline \multicolumn{2}{c}{ The results of stock markets by countries } \\
\hline Country & 2015 years \\
\hline 1. MSCI World index & $-2.21 \%$ \\
\hline 2. JAV & $+1.28 \%$ \\
\hline 3.Japan & $+9.17 \%$ \\
\hline 4. Italy & $+3.14 \%$ \\
\hline 5. Russia & $+3.72 \%$ \\
\hline 6. France & $+0.24 \%$ \\
\hline 7. Germany & $-2.79 \%$ \\
\hline 8. United Kingdom & $-7.02 \%$ \\
\hline 9. Australia & $-9.94 \%$ \\
\hline 10. Turkey & $-31.44 \%$ \\
\hline 11. Mexico & $-14.25 \%$ \\
\hline 12. China & $-12.91 \%$ \\
\hline 13. India & $-8.24 \%$ \\
\hline 14. Canada & $-23.91 \%$ \\
\hline 15. Brazil & $-41.77 \%$ \\
\hline Average & $-9.13 \%$ \\
\hline
\end{tabular}

In 2015 only Japanese, Russian, Italian and French stocks incresed. For the most other stock markets year period of 2015 was not particularly successful:

- Brazil, Turkey and Canada are located in deep crisis.

- The Mexico also has serious problems.

- The stock market of China also has decreased, the results of this market during five years period also is not successful $(-6.66 \%)$.

Oil prices have experienced a pronounced decline in 2014. Since June of 2014 , oil prices decline about $60 \%$. Oil price has $+19 \%$ increase at the beginning of 2015. Since June of 2015 years, the oil price once again decreased about $60 \%$ (see Fig. 5). 


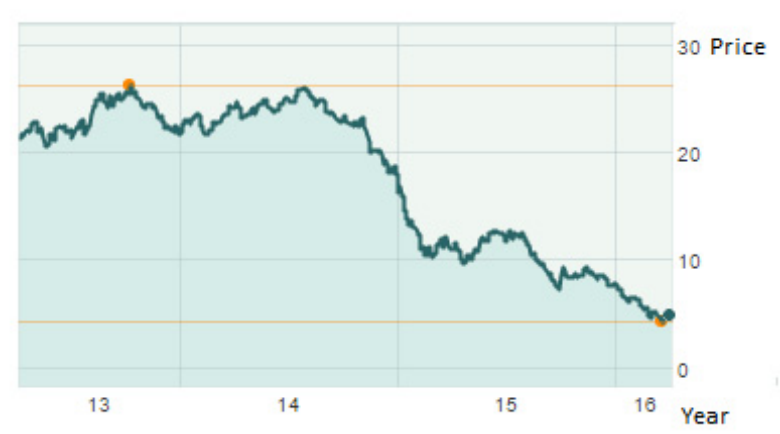

Fig. 5. iPath Goldman Sachs Crude Oil Total Return Index ETN (OIL:US) (Source: Oil price 2016)

Financial analysts explain the causes of the oil depreciation. First of it, the United States oil reserve assets, which there are approximately 100 million barrels higher than the average of the past 5 years at the moment.

The second reason is competition, the increase of other countries oil production capacity. For example, Iraq, which is the second largest oil recipient of Petroleum Exporting Countries (OPEC), in July of 2015 years extracted about 3.06 million barrels per day - this is the all-time record level.

The sanctions for Iran were reduced on July of 2015 due to Tehran's commitment to limit its nuclear program. Basically, this means that Iran will be able more freely export its oil, the country after this agreement plans to increase oil production about 1 million barrels per day. Moreover, the country intends to upgrade its oil production industry and increase production capacity. For this reason the country will invest about 185 billion dollars till 2020.

In conclusion, raw material prices fall due to a combination of supply and demand. The growing oil recovery of shales has the impact on incresing supply, and decelerating economic growth in China has the impact on demand, especially for energy raw materials. At the moment not only oil, but also all raw materials market is not very attractive to investors.

In order to evaluate the situation in the financial markets, the authors examined what stage of the economic cycle in different markets indicates composite leading indicators (see Fig. 6). The following countries are analysed: United States, Euro area (19 countries), China, Japan. These countries are compared with total composite leading indicator (OECD).

Europe and Japan demonstrates the stability. The growth rate of United States are slowly declining now, but the probability of recession is minimal this half of year. The "slowing down" tenden- cy of Chinese economy, which started in 2014 years, stabilizes. The stage of these countries economic cycles is presented in Table 2 .

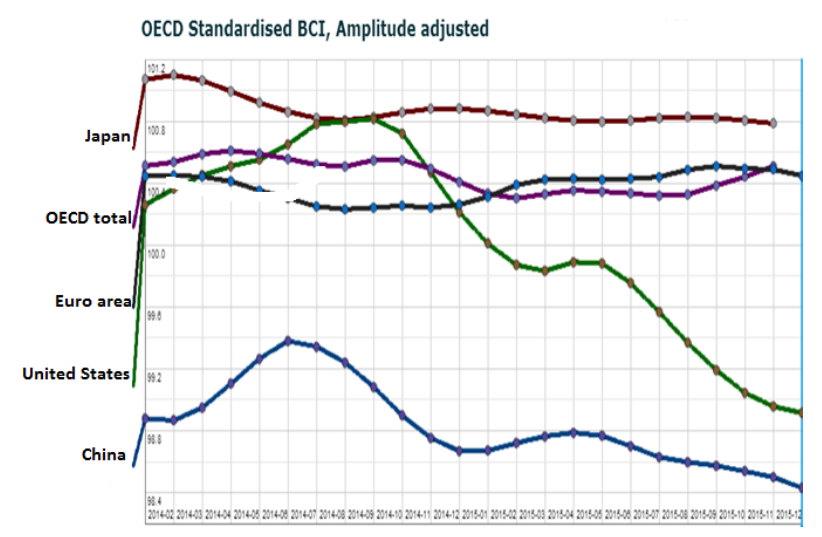

Fig. 6. The composite leading indicators analysis (Source: OECD.Stat 2016)

Table 2. The results of OECD indicators (Source: compiled by authors, using OECD.Stat 2016).

\begin{tabular}{l|c|c|l}
\hline Country/region & $\begin{array}{c}\text { December } \\
\text { of } 2015\end{array}$ & $\begin{array}{c}\text { January } \\
\text { of 2016 }\end{array}$ & Stage \\
\hline OECD total & 99.50 & 99.50 & Stagnated \\
\hline United States & 99.20 & 99.10 & Recession \\
\hline Euro area & 100.60 & 100.60 & Stagnated \\
\hline China & 98.30 & 98.40 & Recovery \\
\hline Japan & 99.80 & 99.80 & Stagnated \\
\hline
\end{tabular}

In conclusion authors provide insight for the financial markets in 2016 year:

- Stock market. It is possible that economic growth will lead the stock markets ahead. At the moment, the perspectives in the Euro area and Japan are assessed positively. The position of United Stated is also favorable, but the fear due to the China's growth and emerging markets could have a negative impact on the stock markets in the short term.

- Commodity market. Oil prices will fluctuate in a narrow margin, it is possible significant rise - in 2016 (towards 65 USD per barrel). The price of gold may fall - the United States rate increase will be a negative factor for the gold.

The financial analysts propose to invest into bonds or hold cash position in the account. More significant rise of the euro will be possible if infliation rise and the essential economic indicators demonstrate positive trends. 


\section{Conclusions}

1. After performing the comparative analysis of theoretical globalization concepts, the authors define globalization as the development of all modern social life relationships and communication, intensification, deepening and acceleration on a global scale, which is associated with the contraction of space and time, when with the assistance of developed technology and networking, the geographical distance does not affect the information rendering, communication or events.

2. After analyzing the the risks posed by globalization, threats and negative effects, it can be said that globalization educes the country's political and economic independence, countries become more vulnerable, increases the sensitivity of the financial markets' expectations and grows inequality.

3. It can be concluded that the impact of globalization is not the same, globalization affects different areas differently: globalization increases the banking crisis, but reduces currency crises, increases inequality between countries, but reduces inequality inside the country.

4. The analysis of financial markets shows, which markets demonstrate their strenghts and which - weaknesses. Only 5 stock markets, from analysing market list, have positive return during 2015 years - Japan $(+9.17 \%)$, USA $(+1.28 \%)$, Italy $(+3.14 \%)$, Russia $(+3.72 \%)$ and France $(+0.24 \%)$. Commodities market has the negative return, especially decreases the price of oil (about 60\%) and gold (about 40\%).

5. Acording to analysis of the composite leading indicators, it can be said that Japan and Europe markets demonstrate stability. The Chinese economy is stabilizing, whereas United States market are slowly decreasing now.

6. The most attractive markets for investors in 2016 should be stock market, particularly markets of Euro area and Japan, as well as bonds market, the least stable will be such financial instruments as gold and oil.

\section{References}

Amit, R.; Zott, Ch. 2004. Global equity capital markets for emerging growth firms: patterns, drivers, and implications for the globalizing entrepreneur. The INSEAD-Wharton alliance on globalizing: strategies for building successful global business. Cambridge: Cambridge University Press.

Baldwin, R. E.; Martin, P. 1999. Two waves of globalization: superficial similarities, fundamental differencies. NBER Working Paper Series, Working Pa- per 6904 [online], [cited 25 January 2016]. Available from Internet:

http://www.nber.org/papers/w6904

Beck, U. 2001. Redefining power in the global age: Eight theses, Dissent 48(4): 83-89.

Beckert, J; Berghoff, H. 2013. Risk and uncertainty in financial markets: a symposium, Socio-Economic Review 11: 497-499. http://dx.doi.org/10.1093/ser/mwt008

Bhagwati, J. N. 1998. The capital myth, Foreign Affairs 77(May-June): 7-12. http://dx.doi.org/10.2307/20048871

Bordo, M.; Eichengreen, B.; Klingebiel, D.; MartinezPeria, M. 2001. Is the crisis problem growing more severe?, Economic Policy 16(32): 52-82. http://dx.doi.org/10.1111/1468-0327.00070

Brakman, S.; Garretsen, H.; Marrewijk, Ch.; Witteloostuijn, A. 2010. Nations and firms in the global economy. Cambridge: Cambridge University Press.

Calvo, G. 2011. Capital inflows, liquidity and bubbles. Columbia University [online], [cited 10 January 2016]. Available from Internet:

http://www.tulane.edu/ economic/seminars/Calvo CapitalInflows.pdf

Ceballos, F.; Didier, T.; Schmukler, S. L. 2012. Financial globalization in emerging countries: diversification vs. offshoring. ADBI Working Paper 389 [online], [cited 27 January 2016]. Available from Internet: http://observgo.uquebec.ca/observgo/ fichiers/40972_DE1.pdf

Dreher, A.; Gaston, N.; Martens, P. 2008. Measuring globalization: gauging its consequences. New York: Springer. http://dx.doi.org/10.1007/978-0387-74069-0

Elliott, K. A.; Kar, D.; Richardson, J. D. 2002. Assessing globalization's critics: "Talkers are no good doers".Working Paper Series WP02-5, Peterson 236 Institute for International Economics [online], [cited 02 February 2016]. Available from Internet: http://ideas.repec.org/h/nbr/nberch/9532.html

Esqueda, O. A.; Assefa, T. A.; Mollick, A. V. 2012. Financial globalization and stock market risk, Journal of International Financial Markets, Institutions and Money 22 (2012): 87-102. http://dx.doi.org/10.1016/j.intfin.2011.07.006

Fischer, S. 1997. Capital account liberalization and the role of the IMF [online], [cited 02 February 2016]. Available from Internet: http://www.imf.org/external/np/speeches/1997/091 997.htm

Galaz, V.; Gars, J.; Moberg, F.; Nykvist, B.; Repinski, C. 2015. Why ecologists should care about financial markets, Trends in Ecology and Evolution 30(10): 571-580. http://dx.doi.org/10.1016/j.tree.2015.06.015

Gatignon, H.; Kimberly, J. R. 2004. The INSEADWharton alliance on globalizing: strategies for 
building successful global businesses. Cambridge University Press.

Giddens, A. 1996. On globalization. Essential matter: globalization excerpts from a keynote address at the UNRISD Conference on Globalization and Citizenship [online], [cited 25 January 2016]. Available from Internet:

http://www.unrisd.org/unrisd/website/newsview.ns f/\%28httpNews $\% 29 / 3$ F2A5BF8EF7300D480256B 750053C7EC?Open Document

Gylys, P. 2003. Globalizacija: ekonominio fundamentalizmo pavojai, iš J. Morkūnienè (sud.). Globalizacija: taikos kultūra, žiniu visuomene, tolerancija: monografija. Vilnius: Lietuvos teisès universitetas, 43-55.

González-Hermosillo, B. 2008. Investors' risk appetite and global financial market conditions, IMF Working paper monetary and capital markets department [online], [cited 02 February 2016]. Available from Internet: https://www.imf.org/ external/pubs/ft/wp/2008/wp0885.pdf

Held, D., et al. 2002. Globaliniai pokyčiai: politika, ekonomika ir kultūra. Vilnius: Margi raštai. 540 p.

Hopkin, P. 2010. Fundamentals of risk management. Understanding, evaluating and implementing effective risk management. United States: Kogan Page Limited. 357 p.

Isard, P. 2005. Globalization and the international financial system. What's wrong and what can be done. Cambridge University Press.

Issing, O. 2000. The globalisation of financial markets. Speech. 2000 September 12, Ottobeuren [online], [cited 25 January 2016]. Available from Internet: https://www.ecb.europa.eu/press/key/date/2000/ht $\mathrm{ml} / \mathrm{sp} 000912$ 2.en.html\#ftn.fn45

JSC “Synergy Finance” annual report. 2016 [online], [cited 17 February 2016]. Available from Internet: http://www.synergy-finance.com/lt/musunaujienos/periodine-finansu-rinku-apzvalga-2016sausis-/5857

Kose, M.; Prasad, A. E.; Rogoff, K.; Wei, S. J. 2010. Financial globalization and economic policies. Handbook of development economics 5: Chapter 65. The Netherlands: North-Holland.

Kropas, S. 2007. Globalizacija ir instituciniai viešosios politikos klausimai Lietuvoje. Lietuvos ekonomika Europoje ir globalioje erdveje. Straipsnių rinkinys. Sudarytojai Lietuvos Respublikos ūkio ministerija, Ekonominių tyrimų centras.

Lane, P. R.; Milesi-Ferretti, G. M. 2010. The crosscountry incidence of the global crisis. IMF Working Paper 10(171). July [online], [cited 29 January 2016]. Available from internet: https://www.imf.org/external/pubs/ft/wp/2010/wp1 0171.pdf
Mikdashi, Z. 2003. Regulating the financial sector in the era of globalisation. Perspectives from political economy and management. Palgrave Macmillan. http://dx.doi.org/10.1057/9781403990112

Mundell, R. A. 1997. Optimum currency areas, in Conference on Optimum Currency Areas, 5 December 1997, Tel-Aviv University, Israel.

Obstfeld, M. 2011. Financial flows, financial crises, and global imbalances, in $15^{\text {th }}$ International Conference on Macroeconomic Analysis and International Finance, 26-28 May 2011, University of Crete, Rethymno, Greece [online], [cited 07 February 2016]. Available from Internet:

http://eml.berkeley.edu/ obstfeld/JIMF2011.pdf

OECD.stat. 2016. Organziation for economic cooperation and development [online], [cited 15 February 2016]. Available from Internet:

http://stats.oecd.org/Index.aspx?DataSetCode=ME I CLI\#

Oil price. 2016 [online], [cited 15 February 2016]. Available from Internet: http://www.bloomberg.com/quote/OIL:US

Rutkauskas, A. V.; Kvietkauskienè, A.; Vyšniauskas, P. 2014. Hunting for sustainable investment return in global financial markets, in The $8^{\text {th }}$ International Scientific Conference "Business and Management”, 15-16 May, 2014, Vilnius Gediminas Technical University, Lithuania. Vilnius: Technika, 858-866. ISSN 2029-4441.

Sandoval, L.; Franca, I. P. 2012. Correlation of financial markets in times of crisis, Physica A 391: 187208. http://dx.doi.org/10.1016/j.physa.2011.07.023

Schmukler, S. L. 2004. Benefits and risks of financial globalization: challenges for developing countries [online], [cited 17 February 2016]. Available from Internet:

http://siteresources.worldbank.org/DEC/Resources /BenefitsandRisksofFinancialGlobalizationSchmuk ler.pdf

Scholte, J. A. 2005. Globalization, a critical introduction. Palgrave Macmillan.

Soros, G. 2002. On globalization. New York: Public Affairs.

Stiglitz, J. E.; Charlton, A. 2006. Fair trade for all: how trade can promote development. Oxford University Press.

Stonehouse, G.; Campbell, D.; Hamill, J., et al. 2004. Global and transitional business. Strategy and management. John Wiley \& Sons, Ltd.

Urbšienè, L. 2011. Globalizacijos samprata: šiuolaikiniai požiūriai, Business: Theory and Practice 12(3): 203-214. http://dx.doi.org/10.3846/btp.2011.21 